ISSN 0258-7122

Bangladesh J. Agril. Res. 34(2) : 263-267, June 2009

\title{
EFFECTS OF PLANTING MATERIAL AND EARTHING-UP ON YIELD AND YIELD CONTRIBUTING ATTRIBUTES OF MUKHI KACHU
}

\author{
S.M.FAISAL ${ }^{1}$, M.A.SALAM ${ }^{2}$, M.S. ISLAM ${ }^{3}$ AND M.I. HOSSAIN ${ }^{4}$
}

\begin{abstract}
An investigation was carried out at Agricultural Research Station, Pahartali, Chittagong during February to August 2002 to select suitable size of planting material and proper time of earthing-up to obtain higher yield of Mukhi Kachu. Three planting materials, primary corm (40g), half cut corm (20g), and secondary corm $(10 \mathrm{~g})$ and four times of earthing-up, 1 month, 2 months, 3 months, and 4 months after planting were used. Different planting materials showed significant difference on weight of total corms/plot, weight of total cormels/plot and cormel yield. Different times of earthing-up showed significant effects on the parameters studied except no. of cormels/hill and weight of cormels/hill. The highest (3.71 t/ha) corm yield was obtained when primary corms were planted and earthing-up was done three months after planting. The combination of P1E ( primary corm x 3 months after planting) gave the highest (8.37 t/ha) cormel yield.
\end{abstract}

Key Words : Mukhi Kachu, corm, cormel, planting material, earthing-up.

\section{Introduction}

Mukhi Kachu (Colocasia esculenia L. Schott) is one of the popular vegetable of Bangladesh. It belongs to the family Araceae, and it is grown as a subsistence food crop throughout tropical and subtropical regions of the world (Ghosh et al., 1988). In Bangladesh, it is cultivated throughout the country in commercial basis (Rashid, 1999). Among the tuber crops, the corm and cormel of Mukhi Kachu are rich source of carbohydrate and also contain sufficient quantity of protein (Verma and Singh, 1996). Although demand of aroids in Bangladesh is increasing day by day but production is not sufficient. The area and gross annual production of aroids in Bangladesh is increasing year after year, but its yield per unit area is very low (7.25 t/ha) (BBS, 2000) as compared with China (17.05 t/ha) and Japan (11.59 t/ha) (FAO, 1999).

Yield of aroids are markedly influenced by planting materials. Many authors reported that seed size had significant influence on the growth and yield of different root crops (Enyi, 1972; Taleb et al., 1973 ; Bhuyan et al., 1982). Besides this, earthing-up after planting considered as good agronomic practice to enhance productivity of Mukhi Kachu. Earthing-up conserved soil moisture, which is very important for growth of the crop. Hence, an attempt was taken to

${ }^{1 \& 3}$ Senior Scientific Officer, ${ }^{2}$ Scientific Officer, HRC, BARI, Gazipur-1701, ${ }^{4}$ Associate Professor, Department of Horticulture and Postharvest Technology, Sher-e-Bangla Agricultural University, Dhaka-1207, Bangladesh. 
select planting material and proper time of earthing-up effective on yield and yield contributing characters of Mukhi Kachu.

\section{Materials and Method}

The experiment was carried out at the Agricultural Research Station, Pahartali, Chittagong during February to August 2002 to see the effects of planting materials and earthing-up on yield and yield contributing characters of Mukhi Kachu. The experiment was set under a randomized complete block design with three replications. There were two factors in this experiment, factor A consisted of three planting materials viz., $\mathrm{P}_{1}$ (primary corm, wt $=40 \mathrm{~g}$ ), $\mathrm{P}_{2}$ (half cut corm, wt $=20 \mathrm{~g}$ ) and $\mathrm{P}$ (secondary corm, wt $=10 \mathrm{~g}$ ) and factor B consisted of four times of earthing-up, viz., $\mathrm{F}_{1}=$ after 1 month, $\mathrm{E}_{2}=$ after 2 months, $\mathrm{E}_{3}=$ after 3 months, and $\mathrm{E}_{4}=$ after 4 months planting were used. The farm was under AEZ (AgroEcological Zone) and physiography of the farm comprised low hills and valleys. The soils are predominantly medium fine textured, $\mathrm{pH}$ ranged from 6.5 to 7.1 and all the macro and micro nutrients were present where the status of some of them are in critical condition. The experimental site was irrigated. For fertilization Cow dung (@12-15 t/ha), Urea (@140-160 kg/ha), TSP (@120-135 kg/ha), and MP (@160-90 kg/ha) were used. Cow dung, TSP, and MP were applied during planting and urea was applied in three installments after planting. The unit plot size was $2.4 \mathrm{~m} \times 1.8 \mathrm{~m}$ and plant spacing was maintained at $60 \mathrm{~cm} \times 45 \mathrm{~cm}$. So total number of plants/plot were 16. Corms of Mukhi Kachu (var. Bilashi) were sown at a depth of 7-8 cm on 5 February 2002. Some plants were infested by red mite (Tetrangchus bicalatus) which was controlled by neuron $(1 \mathrm{ml} / \mathrm{L})$. Weeding, irrigation, miticide spraying, mulching, and other cultural practices were done as and when necessary. The crop was harvested after 206 days of planting when the leaves of all main plants were dead. Data on different yield, such as weight of total corms/plot (kg), no. of cormels/hill, weight of total cormels/plot (kg), corm yield ( $\mathrm{t} / \mathrm{ha}$ ), and cormel yield ( $\mathrm{t} / \mathrm{ha}$ ) were recorded. From the middle rows of each plot, five plants were selected randomly to record data. Recorded data were analyzed using MSTAT-C statistical package. Differences among the means were compared following Duncan's Multiple Range Test (DMRT) at 5\% level of significance.

\section{Results and Discussion}

\section{Effect of planting materials}

Planting materials had significant effect on weight of total corms/plot, weight of total cormels/plot, and cormel yield. Both weight of total corms/plot and weight of total cormels/plot were the highest (1 .32 kg and $3.67 \mathrm{~kg}$, respectively) when primary corms were planted (Table 1). Planting materials had no significant effect on corm yield. The highest (2.77 t/ha) corm yield was obtained from 
primary corns followed by secondary corm (2.49 t/ha) and half cut corm (2.36 t/ha), respectively. The highest cormel yield (6.74 t/ha) was obtained using primary corm as planting material. It might be due to large seed size as large seed stored more food materials, which influenced to initial plant growth and resulted in higher yield. Similar results were reported by Bhuyan et al. (1982), Siddique el. al. (1988) and Rasul et al. (1994). Secondary corm gave the lowest cormel yield (5.21 t/ha).

Table 1. Influence of planting material and earthing-up on yield and yield contributing attributes of Mukhikachu (var. Bilashi).

\begin{tabular}{|c|c|c|c|c|c|}
\hline Treatments & $\begin{array}{c}\text { Wt of total } \\
\text { corms/ plot } \\
(\mathrm{kg})\end{array}$ & $\begin{array}{c}\text { No. of } \\
\text { cormels/ hill }\end{array}$ & \begin{tabular}{|} 
Wt of total \\
cormels/ plot \\
$(\mathrm{kg})$
\end{tabular} & $\begin{array}{c}\text { Corm yield } \\
\text { (t/ha) }\end{array}$ & $\begin{array}{c}\text { Cormel yield } \\
\text { (t/ha) }\end{array}$ \\
\hline \multicolumn{6}{|c|}{ Planting marerial } \\
\hline $\mathrm{P}_{1}$ & $1.32 \mathrm{a}$ & 14.88a & $3.67 a$ & $2.77 a$ & $6.74 a$ \\
\hline $\mathrm{P}_{2}$ & $1.32 \mathrm{a}$ & 14.17a & $2.78 \mathrm{~b}$ & $2.36 \mathrm{a}$ & $5.66 \mathrm{ab}$ \\
\hline $\mathrm{P}_{3}$ & $1.08 \mathrm{~b}$ & $13.84 a$ & $2.63 \mathrm{~b}$ & $2.49 a$ & $5.2 \mathrm{lb}$ \\
\hline \multicolumn{6}{|l|}{ Earthing-Up } \\
\hline $\mathrm{E}_{1}$ & $1.22 \mathrm{~b}$ & $13.94 a$ & $2.52 b$ & $2.30 \mathrm{~h}$ & $5.32 a b$ \\
\hline $\mathrm{E}_{2}$ & $1.22 \mathrm{~b}$ & $14.50 \mathrm{a}$ & $2.90 \mathrm{~b}$ & $2.6 \mathrm{Oab}$ & 6.14ah \\
\hline$E_{3}$ & $1.52 a$ & $15.82 \mathrm{a}$ & $4.09 a$ & $2.99 a$ & $6.99 a$ \\
\hline $\mathrm{E}_{4}$ & $0.99 \mathrm{~b}$ & $12.92 \mathrm{a}$ & $2.56 \mathrm{~b}$ & $2.27 \mathrm{~b}$ & $5.04 \mathrm{~b}$ \\
\hline
\end{tabular}

Means followed by a common letter (s) are not significantly different at $5 \%$ level of probability as per DMRT.

\section{Effect of earthing-up}

Effect of earthing-up was found significant on all the parameters studied except number of cormels/hill (Table 1). Weight of total corms/plot were the highest $(1.52 \mathrm{~kg})$ when earthing-up was done three months after planting which was followed by $E_{1}(1.22 \mathrm{~kg}), E_{2}(1.22 \mathrm{~kg})$ and $E_{3}(0.99 \mathrm{~kg})$, respectively. Similar results were also found in case of weight of total cormels/plot. The highest corm yield (2.99 t/ha) and the highest cormel yield (6.99 t/ha) were obtained when earthing-up was done three months after planting. The lowest yield of corm (2.27 $\mathrm{t} / \mathrm{ha}$ ) was obtained from $E_{4}$, which was statistically identical with rest of the treatments. The lowest cormel yield (5.04 t/ha) was also obtained when earthingup was done after 3 months of planting. Rashid (1999) mentioned the advantages of earthing up and suggested that 2-3 times earthing-up were helpful for Mukhi Kachu production. 


\section{Effect of interaction of earthing-up and planting materials}

The interaction between planting materials and earthing-up was found significant on all the parameters studied (Table 2). Weight of total corms/plot were the highest $(1.93 \mathrm{~kg})$ when primary corms were planted and earthing-up was done at three months after planting, followed by $\mathrm{P}_{2} \mathrm{E}_{1}(1.64 \mathrm{~kg})$. Most of the treatment combinations showed moderate result in this parameter. Weight of total corms per plot was the lowest $(0.92 \mathrm{~kg})$ when secondary corms were planted and earthing-up was done at four months after planting. Regarding number of cormels/hill, the combination $\mathrm{P}_{1} \mathrm{E}_{3}$ gave maximum number (20.00) followed by $\mathrm{P}_{2} \mathrm{E}_{1}$ (17.83), $\mathrm{P}_{3} \mathrm{E}_{2}$ (14.90), and $\mathrm{P}_{3} \mathrm{E}_{3}$ (14.47) and minimum number (11.33) of

Table 2. Interaction effects of planting material and attributes of Mukhikachu (var. Bilashi).

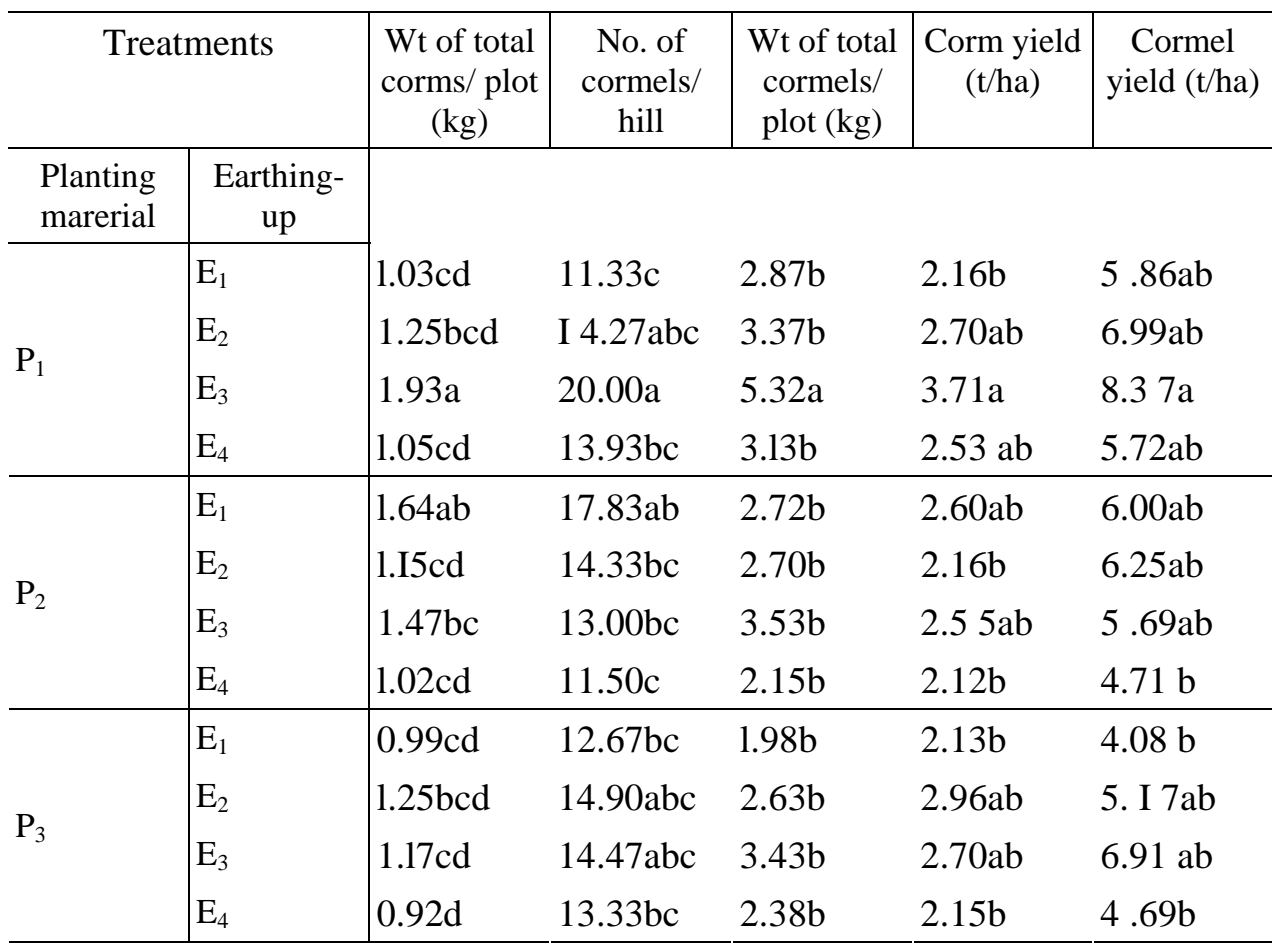

Means followed by a common letter (s) are not significantly different at $5 \%$ level of probability as per DMRT.

$\mathrm{P}_{1}=$ primary corm, $\mathrm{P}_{2}=$ half cut corm, $\mathrm{P}_{3}=$ secondary corm, $\mathrm{E}_{1}=$ earthing-up after 1 month of planting, $E_{2}=$ earthing-up after 2 months of planting, $E_{3}=$ earthing-up aftei 3 months of planting, $\mathrm{E}_{4}=$ earthing-up after 4 months of planting.

cormels/hill was found in $\mathrm{P}_{1} \mathrm{E}_{1}$ followed by $\mathrm{P}_{2} \mathrm{E}_{4}$ (11.50). In case of weight of total cormels/plot, the highest (5.32 kg) weight was observed in $\mathrm{P}_{1} \mathrm{E}_{3}$ treatment. 
By using medium size seed cormel (28 g), Salam et al. (2003) obtained maximum weight $(31.03 \mathrm{~kg}$ ) of cormels/plot. Both the corm and cormels yield were the highest (3.71 and 8.37 t/ha, respectively) when primary corms were planted and earthing-up was done three months after planting. The lowest corm yield (2.12 t/ha) was found in the treatment $\mathrm{P}_{2} \mathrm{E}_{4}$ and the lowest cormel yield (4.08 t/ha) was observed in $\mathrm{P}_{3} \mathrm{E}_{1}$ treatment. Normally this variety gives 25-30 t/ha yield, whereas its yield may increase upto 40 t/ha when it was cultivated following advanced technology (BARI, 2004). But in this experiment, 4 to 5 times less yield was obtained as compared to previous information. One of the main reasons behind this low yield was that the fertility as well as the productivity of the soil of Pahartali was very low.

\section{References}

BARI (Bangladesh Agricultural Research Institute). 2004. Handbook on Agrotechnology. Bangladesh Agril. Res. Inst., Gazipur-1701, Bangladesh. p.229-230.

BBS (Bangladesh Bureau of Statistics). 2000. Monthly Statistical Bulletin of Bangladesh, August. Minis. Plan., Govt. People’s Repub., Bangladesh. p.55.

Bhuyan, M. A. J., M. M. Haque and R. Haque. 1982. Effect of seed size and spacing on the yield of Mukhi kachu (Colocasia esculenla). Bangladesh Hort. 10(2): 5-8.

Enyi, B. A. C. 1972. The effect of seed size and spacing on growth and yield of lesser yam (Dioscorea esculenta). Ann. Appi. Biol. 72: 53-60.

FAO. Quarterly Bulletin of Statistics. 1999. Food and Agriculture Organization of the United Nations, Rome, Italy. 12(3/4):45.

Ghosh, S. P., T. Ramanjuam, J. S. Jos., S. N. Moorthy and R. G. Nair. 1988. Tuber Crops. Oxfbrd and IBH Publishing Co. Pvt. Ltd., New Delhi. p. 403.

Rashid, M. M. 1999. Sabji Bijnan (in Bengali). Rashid Publishing House, 94 Old DOHS, Dhaka-1206, p. 448-452.

Rasul, M. G., M. S. Akter, M. S. Nahar, M. A. Mannan and M. M. Rashid. 1994. Effect of mulches and seed types on the growth, yield attributes and yield of Mukhi Kachu. Bangladesh J. Sci. Ind. Res. 29(3): 53-61.

Siddique, A. A., M. Dhar and M. G. Rabbani. 1988. Effects of cormel size and plant spacing on the yield of Mukhi Kachu. Bangladesh J. Agril. Res. 13 (1): 3 1-36.

Salam, M.A., , M.A. Siddique, M.A. Rahim, M.S. Ahmed and P.C. Golder. 2003. Effects of different doses and time of application of urea and muriate of potash on the growth and yield of Mukhi Kachu (Colocasia esculenta ). Bangladesh J. Prog. Sci. \& Tech. 1(1): 85-88.

Taleb, A., A. Husain and A. Siddique. 1973. Effect of seed size and spacing on the yield of potato. Indian J. Agric. Sci., 43: 237-240.

Verma, R. B. and P. K. Singh. 1996. Effect of nitrogen and potassium levels on growth, yield and nutrient uptake of Colocasia. J. Root Crops. 22(2): 139-143. 